\title{
The Properties of Fuel and Characterization of Functional Groups in Biodiesel -Water Emulsions from Waste Cooking Oil and Its Blends
}

\author{
Annisa Bhikuning ${ }^{1,2 *}$, Jiro Senda ${ }^{1}$ \\ ${ }^{1}$ Mechanical Engineering Department, Doshisha University, 610-0332, Kyotanabe City, Kyoto, Japan \\ ${ }^{2}$ Mechanical Engineering Department, Trisakti University, 11440, Jakarta, Indonesia \\ *Correspondence: E-mail: annisabhi@trisakti.ac.id
}

\section{A B STRACT}

Studying biodiesel as an alternative fuel is important for finding the most suitable fuel for the future. Biodiesel from waste cooking oil is one of the alternative fuels to replace fossil oil. Waste cooking oil is the used oil from cooking and is taken from hotels or restaurants. The emulsion of waste cooking oil and water is produced by adding water to the oil, as well as some additives to bind the water and the oil. In this study, the fuel properties of $100 \%$ biodiesel waste cooking oil are compared to several blends by volume: $5 \%$ of biodiesel waste cooking oil blended with 95\% diesel oil (BD5), $10 \%$ of biodiesel waste cooking oil blended with $90 \%$ of diesel oil (BD10), $5 \%$ of biodiesel waste cooking oil blended with $10 \%$ of water and $18.7 \%$ of additives (BDW18.7), and 5\% of biodiesel waste cooking oil blended with $10 \%$ of water and $24.7 \%$ of additives (BDW24.7). The objectives of this study are to establish the properties and characteristics of the FTIR (Fourier-transform infrared spectroscopy) of biodiesel-water emulsions from waste cooking oil and to compare them to other fuels. The chemical properties of the fuels are analyzed by using the ASTM D Method and FTIR to determine the FAME (fatty acid methyl ester) composition of biodiesel in diesel oil. The results showed that the addition of additives in the water-biodiesel oil increases the viscosity, density, and flash point. However, it decreased the caloric value due to the oxygen content in the fuel.

\section{ARTICLE INFO}

\section{Article History:}

Submitted/Received 27 Aug 2019

First revised 17 Dec 2019

Accepted 27 Jan 2020

First available online 29 Jan 2020

Publication date 01 Mar 2020

Keyword:

Biodiesel,

Waste cooking oil,

Water emulsion

Fuel properties,

FTIR. 


\section{INTRODUCTION}

Biodiesel is a fuel that is produced from vegetable oil, such as jatropha oil, palm oil, coconut oil, and waste cooking oil. Biodiesel is one of the promising fuels to replace fossil fuels because it is a source of renewable energy (Nayaggy \& Putra, 2019) and can reduce pollutants such as CO, NOx, and SOx (Farobie \& Hasanah, 2016). Fossil fuels, on the contrary, are the biggest contributors in the global pollutions in the world. The pollutants may consists of CO, NOx, SOx, particulate matter, and non-burned hydrocarbons (Juan et al., 2011). Therefore, it is important to find alternative energy sources to reduce the pollution from fossil fuels and to improve the environment.

Water in diesel or biodiesel emulsion derives from the micrometer-sized droplets, which affects combustion (Lif \& Holmberg, 2006). This experimental observation (Cook \& Law, 1978) and theoretical insight were already made around 40 years ago (Ballester et al., 1996). In water emulsion diesel oil, water is homogeneously mixed with diesel oil. This mixing happens due to a surfactant that assists to create a balanced composition in the emulsion fuel. Moreover, the emulsion of water in the fuel can lead to a change in momentum, which may improve the mixing of air and fuel. In addition, the nanosize of the water particles may trigger microexplosions, which can also increase fuel atomization (Armas et al., 2005).

Many reseachers studied regarding to biodiesel water emulsion. It was found that $15 \%$ of water in biodiesel emulsions can decrease the NOx , $\mathrm{CO}$, and smoke emissions compared to diesel oil (Kinoshita et al., 2004; Lawson et al., 1986; Awang \& May, 2008). However, another study found that $\mathrm{CO}$ emission in different loads was higher than diesel oil probably because of a lower combustion temperature (Subramanian et al., 2011). Moreover, a composition of $5 \%$ of water emulsion in palm oil blended with diesel oil can reduce CO, NOx, and black smokes (Narkpakdee et al., 2012). Furthermore, $30 \%$ of water emulsion with eucalypus oil biodiesel can reduce smoke and NOx emissions up to 30 to 32\% (Senthur \& Ravikumar, 2016). Yoshimoto et al. (2008) observed that $20,40,60 \%$ of water in biodiesel emulsions with used fying oil can reduce $\mathrm{CO}$, NOx, and $\mathrm{HC}$ emissions as compared to diesel oil.

In this study, we investigated the fuel properties of biodiesel-water emulsions from waste cooking oil and compared these properties to those of other fuels. Some properties, such as density, kinematic viscosity, flash point, Cetane Index, and FTIR analysis, are explained.

\section{MATERIALS AND METHODS}

\subsection{Biodiesel and diesel oil}

Biodiesel waste cooking oil was purchased from PT. Bali Hijau Biodiesel, Indonesia. Commercial diesel oil was produced by the Indonesian Oil Company, and the additives were obtained from the Mechanical Engineering Department, Trisakti University, Jakarta (Hafnan, 2008). The quality of the fuels was tested according to the ASTM D (American society for testing and materials) method.

In this study, biodiesel waste cooking oil was blended with diesel oil, water, or additives in several volume fractions: $5 \%$ of biodiesel waste cooking oil blended with $95 \%$ of diesel oil (BD5), $10 \%$ of biodiesel waste cooking oil blended with $90 \%$ of diesel oil (BD10), $5 \%$ of biodiesel waste cooking oil blended with $10 \%$ of water and $18.7 \%$ of additives (BDW18.7), and 5\% of biodiesel waste cooking oil blended with $10 \%$ of water and $24.7 \%$ of additives (BDW24.7).

The properties were measured by the Petrolab Services Company in Indonesia. The FTIR (Fourier-transform infrared 
spectroscopy) spectra tests were done by Thermo Scientific Nicolet iS10.

\subsection{The making of biodiesel water emulsions.}

In this study, two samples of emulsions of biodiesel waste cooking oil and water were prepared by volume: $10 \%$ of Water, $5 \%$ of biodiesel waste cooking oil, $100 \%$ of diesel oil, and the additives were varied from $18.7 \%$ and $24.7 \%$, respectively.

The additives in volume fractions of $18.7 \%$ and $24.7 \%$ were chosen to avoid the heterogeneity in the fuel. Whith these amounts, water, and diesel oil can be merged together. The fuels can be visualized in a 100 and 200x magnification (Bhikuning, 2008), as shown in Figure 3.

\section{RESULTS AND DISCUSSION}

\subsection{Chemical Properties}

According to Chhetri et al. (2008), the fatty acid composition of biodiesel waste cooking oil is dominated by oleic $(59.7 \%)$, linoleic (19.31\%), linolenic (6.82\%), and palmitic $(5.18 \%)$ acid. In addition, lignoceric $(0.08 \%)$, arachidic $(0.16 \%)$, and myristic $(0.11 \%)$ acid are represented in small amounts.

\subsubsection{Density}

Density is one of the most important properties of biodiesel. Density is defined as mass per unit of volume. Higher densities of biodiesel can cause problems in the engine, such as deterioration of the atomization of fuel (Xuea et al., 2011). The results of the density measurements are shown in Figure 1 . The results are obtained by the ASTMD 1298-12b method. From Figure 1, it can be seen that more additives added to the diesel oil will increase the density of the fuel. The results show that pure biodiesel of waste cooking oil (BD100) has the highest density of about 881.6 $\mathrm{kg} / \mathrm{m}^{3}$ and that BDW24.7 has the second- highest density of $869.6 \mathrm{~kg} / \mathrm{m}^{3}$. BD5 reached a density of $825.4 \mathrm{~kg} / \mathrm{m}^{3}$ while, BD10 was $833.6 \mathrm{~kg} / \mathrm{m}^{3}$ and BDW18.7 was $842.9 \mathrm{~kg} / \mathrm{m}^{3}$.

Awang and May (2008), Abdurrahman et al. (2016), and Narkpakdee et al. (2012) showed that the density of biodiesel-water emulsions increased with an increasing percentage of water in the fuel.

Figure 1 shows that more additives added to the diesel oil increased the density in the fuel.

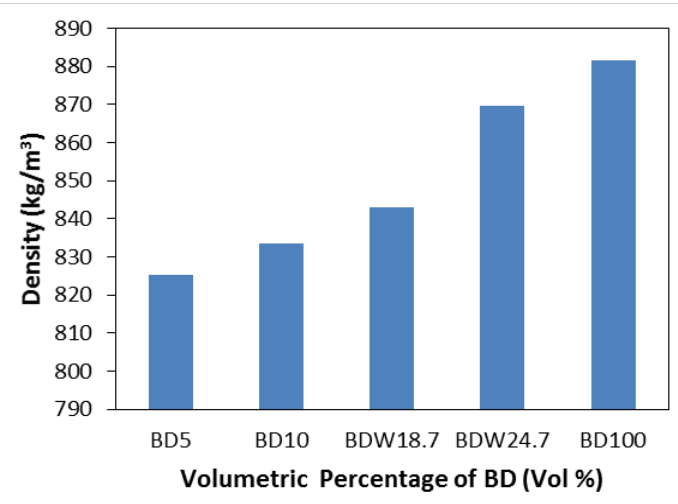

Figure 1. Density characteristic from various fuels

\subsubsection{Kinematic Viscosity}

Kinematic viscosity of fuel is an important property to understand. In this study, kinematic viscosity was examined using ASTM D 445. The results are shown in Figure 2.

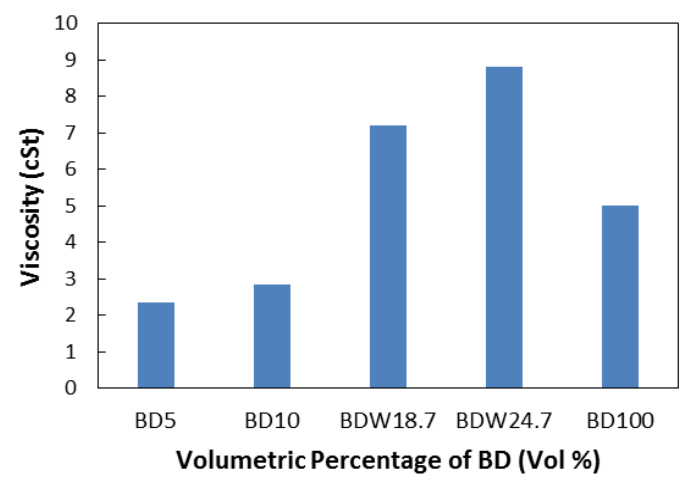

Figure 2. Kinematic Viscosity characteristic from various fuels. 


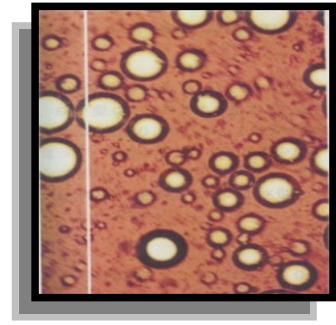

(a)

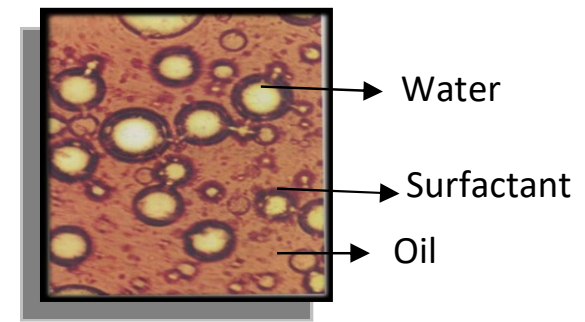

(b)

Figure 3. (a) Ilustration of biodiesel and water in emulsion (enlargement 100x), (b) Ilustration of biodiesel and water in emulsion (enlargement $200 \mathrm{x}$ ) (Bhikuning, 2008)

Figure 2 shows that BDW24.7 has the highest viscosity of all the fuels tested. The high viscosity makes it difficult for a fuel to atomize and can affect combustion deterioration (Xuea et al., 2011). Fuel atomization and volatility are affected by viscosity (Borhanipur et al., 2014). The viscosity of pure biodiesel oil is higher than that of the blends. Blending pure biodiesel oil with diesel oil can decrease the viscosity of the fuel. Figure $\mathbf{2}$ also shows that additives in the fuel increase its viscosity. Similar trends were observed by Karim et al. (2014), in which biodiesel emulsion was found to have a higher viscosity than diesel oil. The viscosity of BDW24.7 is the highest volume among all the fuels tested (with a value of 8.805 cSt). Moreover, the viscosity of BDW18.7 reached a value of 7.217 Cst.

Narkpakdee et al. (2012) showed that the viscosity of biodiesel-water emulsions was increased by an increase in the composition of the fuel. In addition, Awang, and May (2008) demonstrated that the viscosity of biodiesel-water emulsions was increased by an increase in the concentration of water in the fuel.

\subsubsection{Flash Point}

The flash point was calculated using the ASTMD 93-16a method. The flash point is defined as the lowest temperature of the fuel that can provide a combustible mixture

between fuel and air (Borhanipur et al., 2014). The values of the flash point for diesel oil were in the range of $55-66^{\circ} \mathrm{C}$, and for biodiesel between 110 and $180^{\circ} \mathrm{C}$ (Bhikuning et al., 2018).

From Figure 4, it can be seen that the amount of biodiesel blended in the fuel can affect the value of the flash point. The higher concentration of additives resulted, the higher the flash point of the fuel. The flash point of BDW24.7 is $80^{\circ} \mathrm{C}$, which is higher than that of BDW18.7 at $77^{\circ} \mathrm{C}$. Similar results were obtained by Senthur and Ravikumar (2016) who showed that the flash point of emulsified biodiesel is higher than that of diesel oil but slightly lower than that of biodiesel.

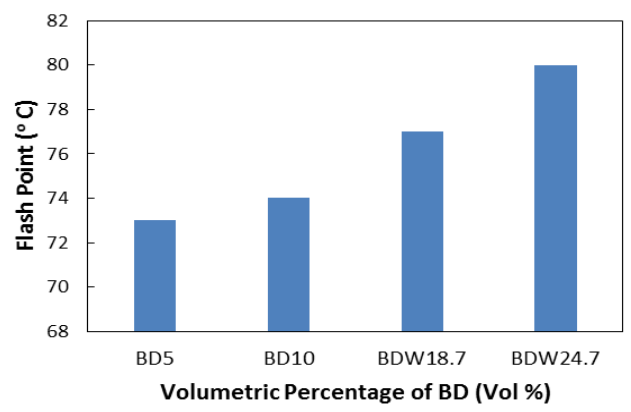

Figure 4. Flash point characteristic from various fuel. 


\subsubsection{Cetane Index}

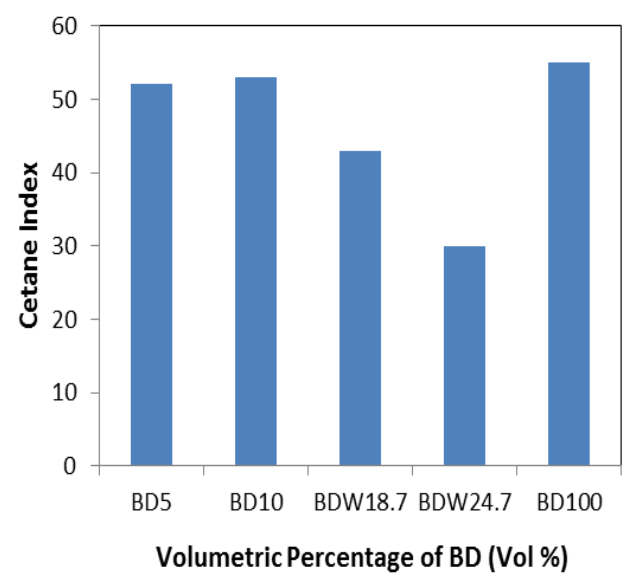

Figure 5. Cetane index characteristic from various fuels

The cetane index is calculated based on the density and the volatility from the fuel (Anggono et al., 2018). The ignition quality of diesel oil can be described on the Cetane Number (Knothe, 2003).

The value of cetane number should not be too high nor too low. The incomplete combustion and smoke can appear if the cetane number is too high because the combustion can occur before the fuel and air are properly mixed (Knothe, 2003).

The incomplete combustion can also occur if the cetane number is too low because the engine warms up too slowy, resulting in engine roughness, higher air temperature, and misfiring (Knothe, 2003). The cetane index in BDW18.7 is 17.30 to $18.86 \%$, which is lower than BD5 and $\mathrm{BD} 10$. Moreover, the cetane index of BDW24.7 is the lowest among all fuels tested. The addition of additives in the fuel can decrease the value of the cetane index.

\subsubsection{Caloric Value}

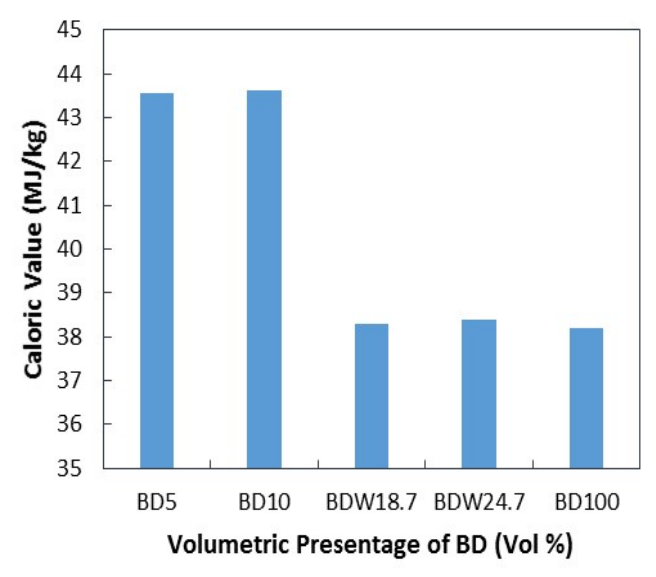

Figure 6. Caloric values from various fuels

Figure 6 shows the caloric values of several fuels. From Figure 6, it can be seen that the biodiesel-water emulsions BDW18.7 and BDW24.7 have a low caloric value. Adding water and additives (BW18.7) in biodiesel can cause a decrease of $12.08 \%$ in caloric value as compared to BD5. The caloric values of BDW18.7 and BDW24.7 are nearly the same with that of BD100. As can be seen in Figure 6 the caloric value of BDW24.7 is $11.89 \%$ which is, lower than that of BD5. The low caloric value of biodiesel and biodiesel-water emulsion is due to their high oxygen content. Nevertheless, the combustion efficiency of biodiesel and biodiesel-water emulsion will be high because of the oxygen content in the fuel. Similar results were found by Awang and May (2008) who found that the caloric value can be decreased up to $5.46 \%$ by adding $15 \%$ of water to biodiesel emulsion. Narkpakdee et al. (2012) and Senthur \& Ravikhumar (2016) showed that adding water to biodiesel emulsions can decrease the caloric value of biodiesel-water emulsions compared to diesel oil. 


\subsubsection{Distillation}

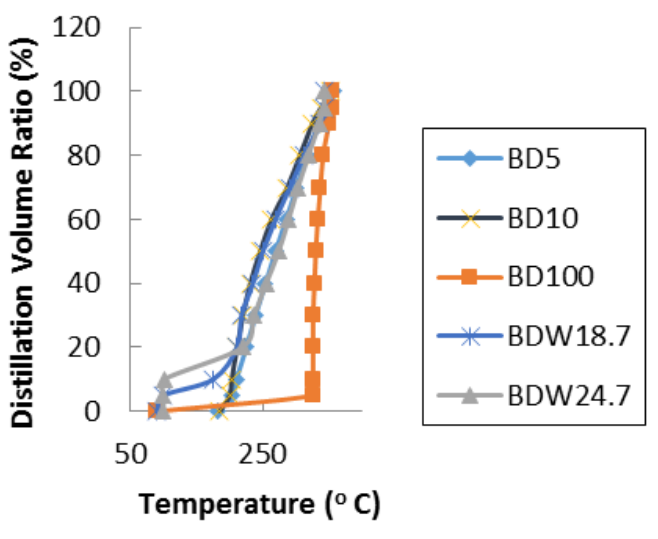

Figure 7. Distillation Curve from various fuels

The distillation was calculated by the ASTMD 86-17 method. The distillation curves are shown in Figure 7. This figure shows that BD100 has the highest volatility among all fuels tested. This can indicate that BD100 has poor spray characteristics as compared to other fuels. As seen in Figure 7, the distillation of BDW18.7 is nearly the same as that of BD10. This can be indicated that BDW18.7 has better in spray characteristics than BDW24.7.

\subsection{Infrared Spectrometry Analysis /FTIR}

FTIR spectrometry is able to predict the wavenumber of biodiesels (Cunha et al., 2017) and can detect the methyl peak positions of transesterification in biodiesel (Barone, 2007). The FTIR analysis in Figures $\mathbf{8}, \mathbf{9}, \mathbf{1 0}, \mathbf{1 1}$, and 12 refers to infrared spectroscopy absorptions table (Nandiyanto et al., 2017; Nandiyanto et al., 2019). Detail analysis results are showed in Table 1.

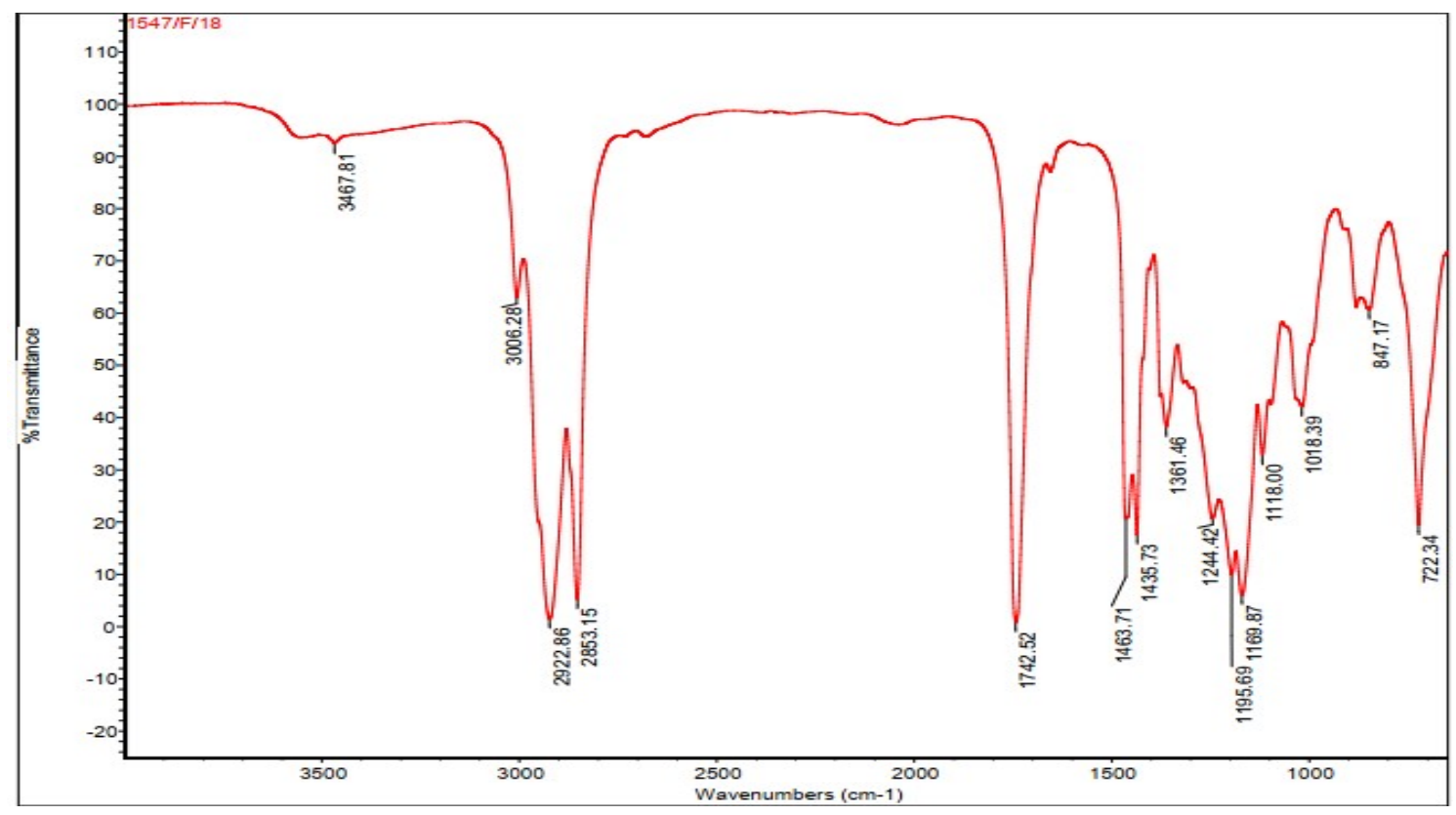

Figure 8. Infrared Spectrometry of BD100 
101 | Indonesian Journal of Science \& Technology, Volume 5 Issue 1, January 2020 Hal 95- 108

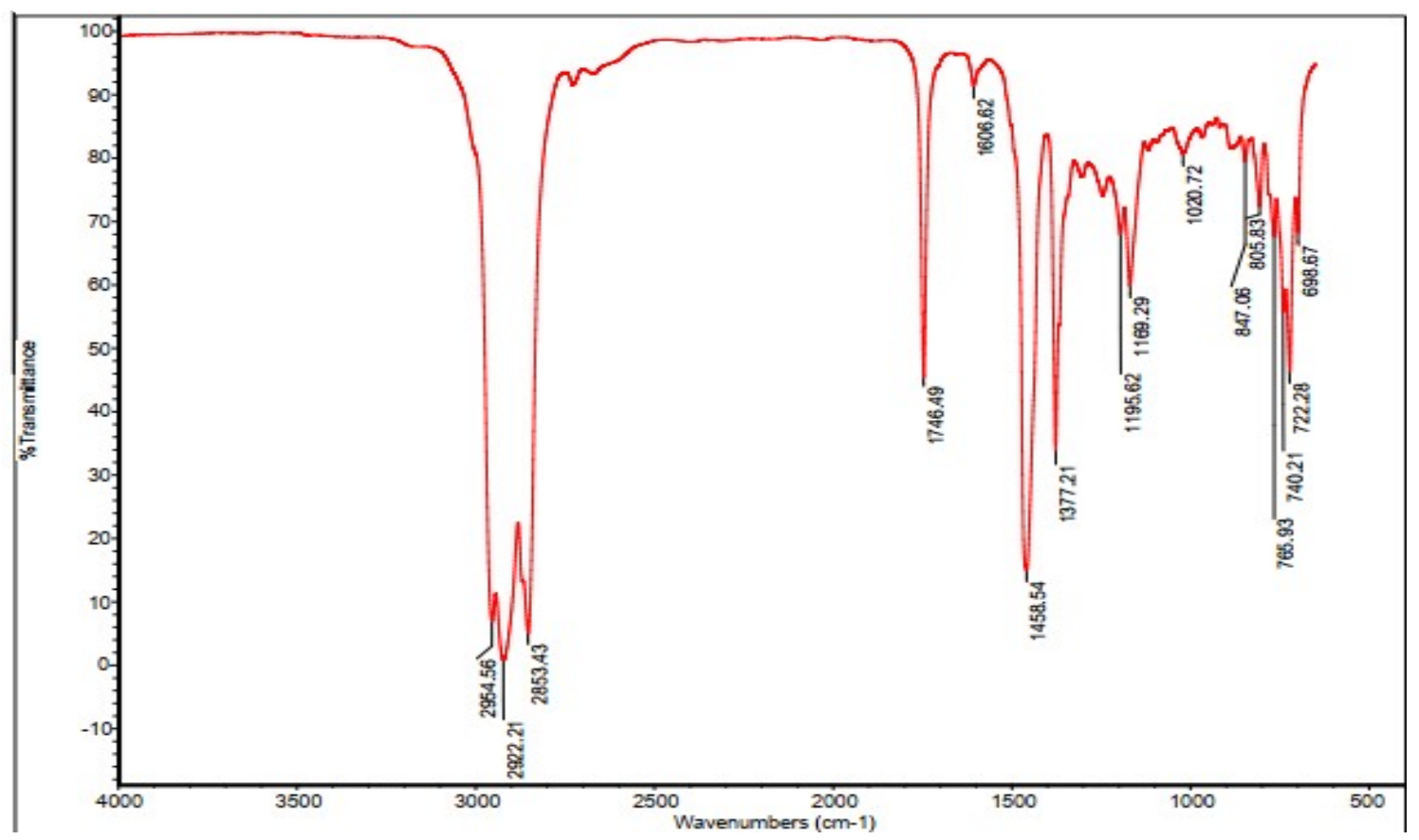

Figure 9. Infrared Spectrometry of BD10

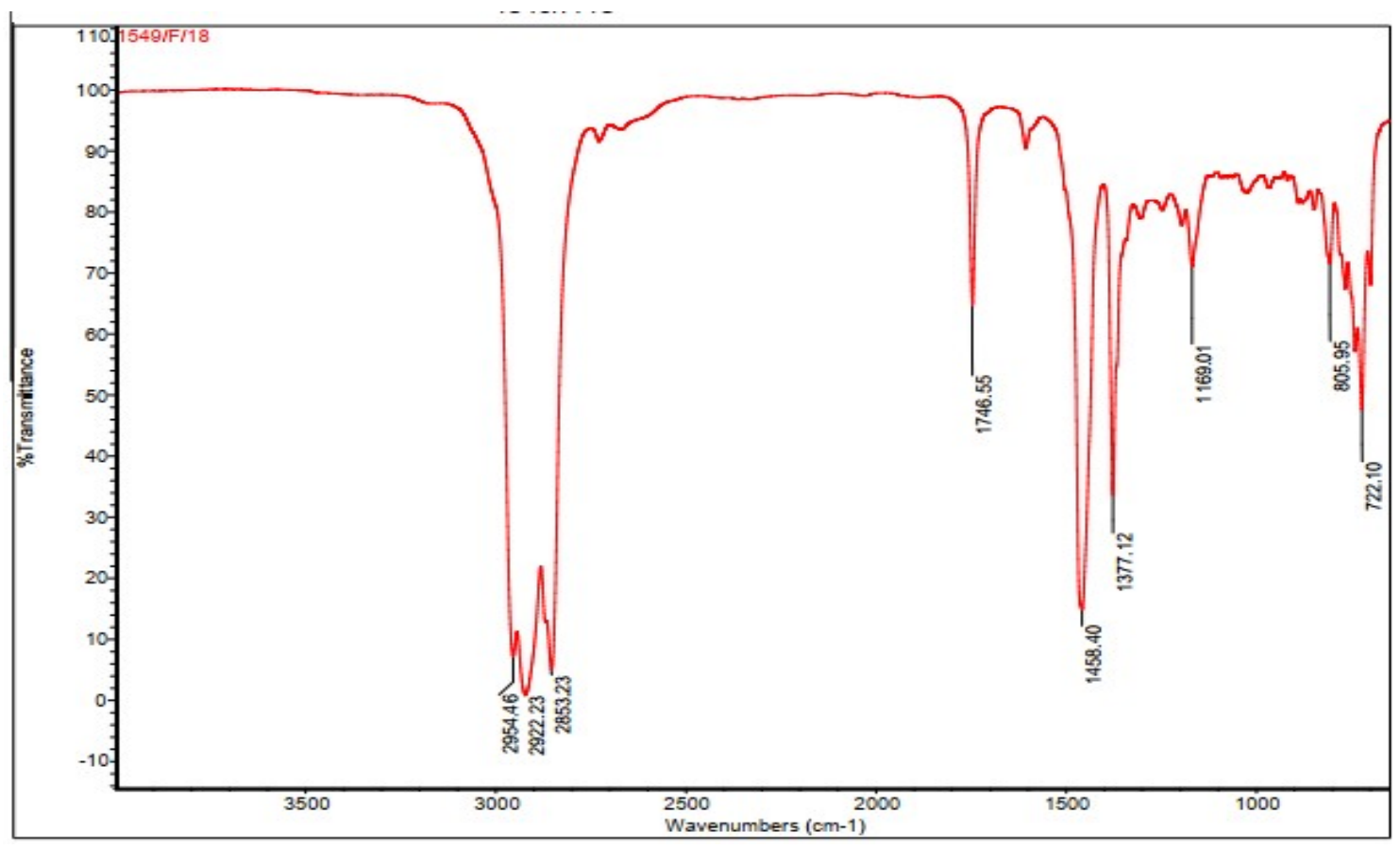

Figure 10. Infrared Spectrometry of BD5 
Annisa Bhikuning, et.al. Groups in Biodiesel -Water Emulsions from Waste Cooking Oil... | 102

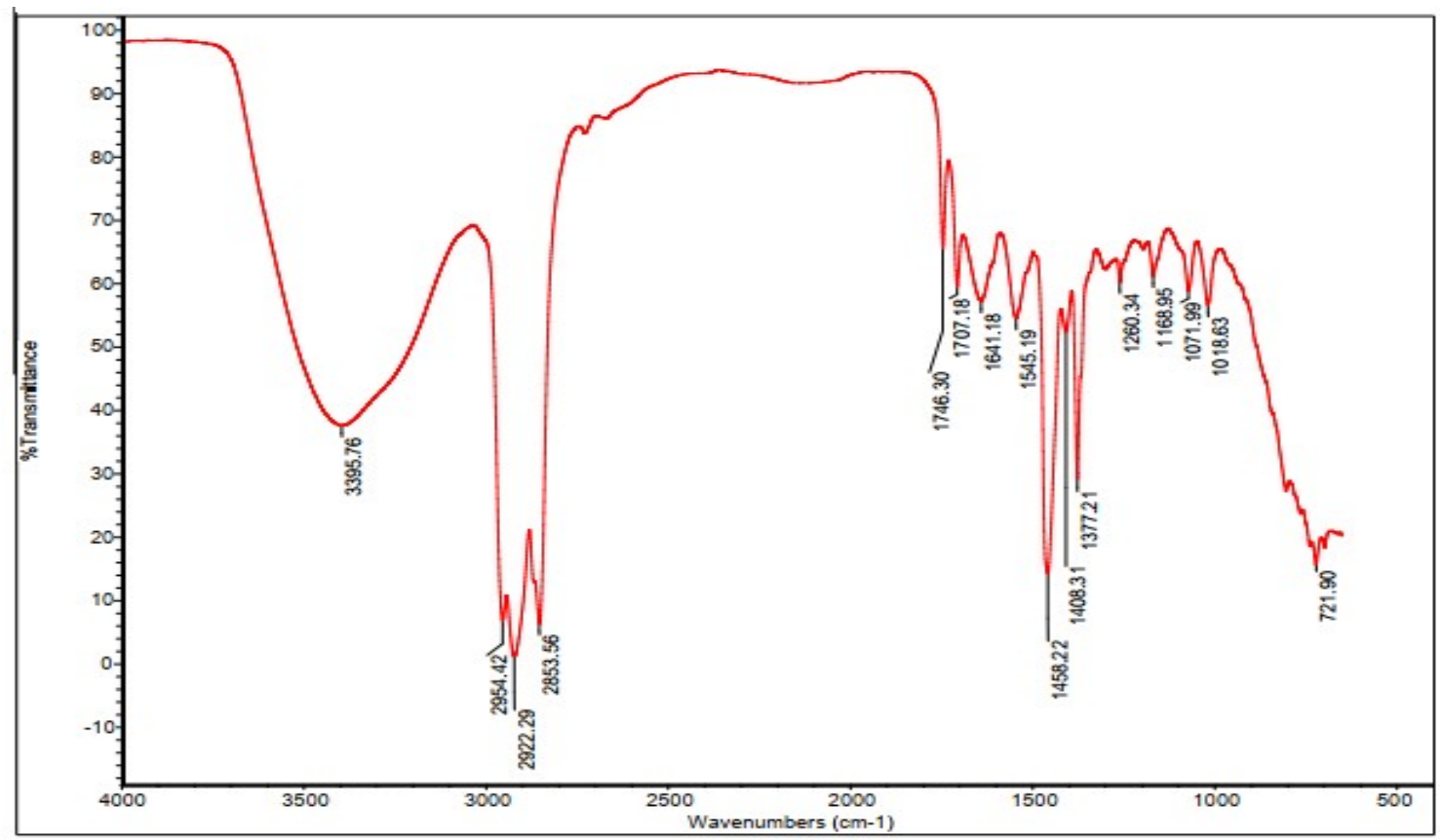

Figure 11. Infrared Spectrometry of BDW18.7

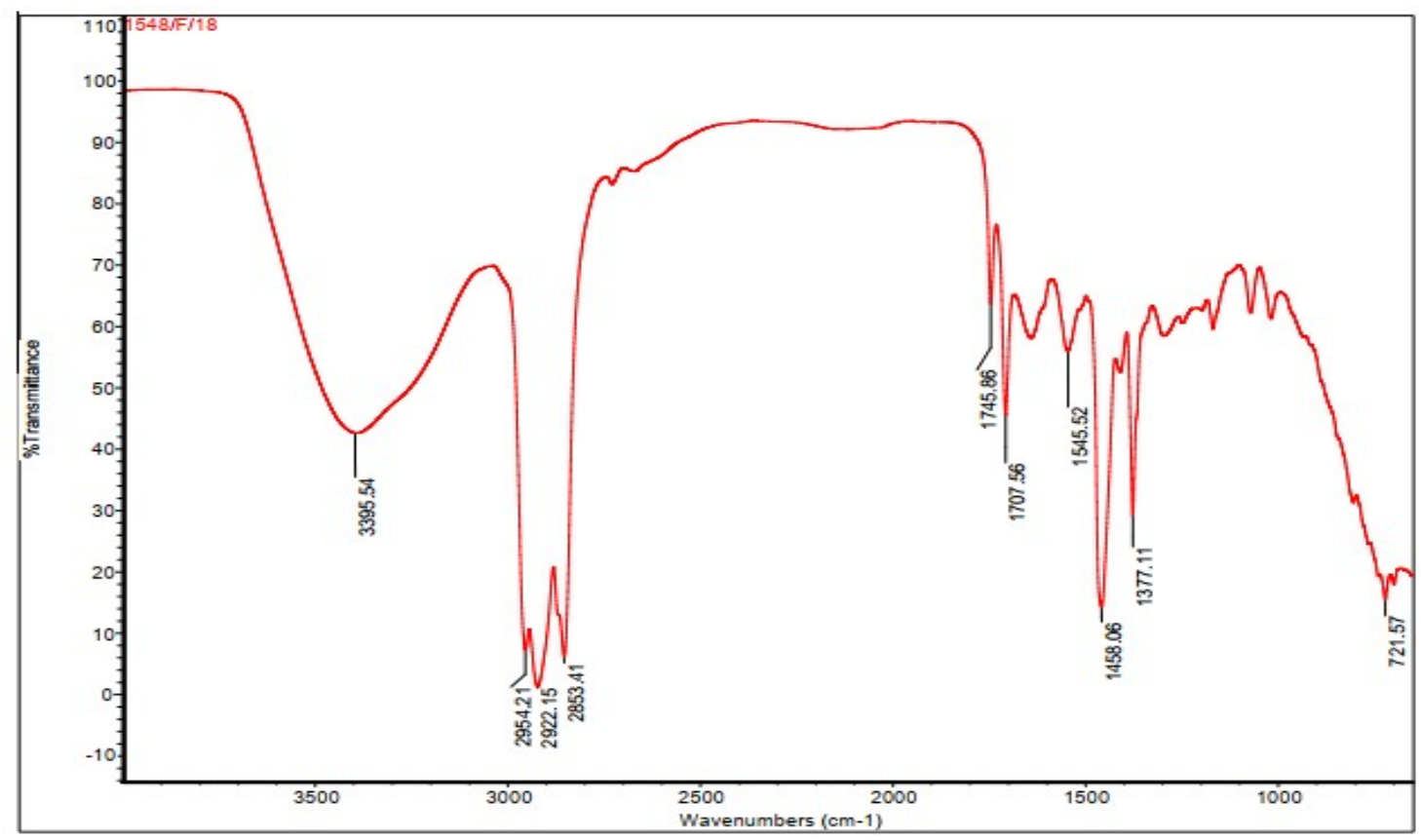

Figure 12. Infrared Spectrometry of BDW24.7 
103 | Indonesian Journal of Science \& Technology, Volume 5 Issue 1, January 2020 Hal 95-108

Table 1. FTIR peaks identified in various fuels

\begin{tabular}{|c|c|c|c|c|c|}
\hline \multirow[t]{2}{*}{ No. } & \multirow[t]{2}{*}{ Fuel } & \multicolumn{2}{|c|}{ Wavenumber $\left(\mathrm{cm}^{-1}\right)$} & \multirow{2}{*}{$\begin{array}{c}\text { Functional Group/ } \\
\text { Assignment }\end{array}$} & \multirow[t]{2}{*}{ Literature } \\
\hline & & Experiment & Literature & & \\
\hline \multirow[t]{10}{*}{1} & BD100 & 3467.81 & $3460-3510$ & O-H stretch alcohol & $\begin{array}{l}\text { (Coates, 2000; Rabelo } \\
\text { et al., 2015; Soares et } \\
\text { al., 2008) }\end{array}$ \\
\hline & & 3006.28 & $3000-3100$ & $\begin{array}{l}\mathrm{O}-\mathrm{H} \text { stretch } \\
\text { (Carboxylic acid) }\end{array}$ & $\begin{array}{l}\text { (Coates, 2000; } \\
\text { Nandiyanto et al., } \\
\text { 2019) }\end{array}$ \\
\hline & & & & $=\mathrm{C}-\mathrm{H}$ stretch (Alkenes) & \\
\hline & & & & C-H stretch (Aromatics) & \\
\hline & & 2922.86 & $2915-2935$ & $\mathrm{C}-\mathrm{H}$ methylene & (Coates, 2000) \\
\hline & & 2853.15 & $2845-2865$ & $\mathrm{C}-\mathrm{H}$ stretch $\left(>\mathrm{CH}_{2}\right)$ & $\begin{array}{l}\text { (Dovbeshko et al., } \\
2000 \text { ) }\end{array}$ \\
\hline & & 1742.52 & $1725-1750$ & $\mathrm{C}=\mathrm{O}$ ester & $\begin{array}{l}\text { (Coates, 2000; } \\
\text { Saifuddin et al., 2014) }\end{array}$ \\
\hline & & 1435.73 & $1430-1470$ & Methyl C-H bend & (Coates, 2000) \\
\hline & & 1169.87 & $1130-1190$ & $\mathrm{CN}$ stretch & (Coates, 2000) \\
\hline & & 722.34 & $700-800$ & C-Cl Stretch & (Coates, 2000) \\
\hline \multirow[t]{9}{*}{2} & BD10 & 2964.56 & $2950-2970$ & $\mathrm{C}-\mathrm{H}$ methyl stretch $\left(\mathrm{CH}_{3}\right)$ & $\begin{array}{l}\text { (Coates, 2000; } \\
\text { Nandiyanto et al., } \\
\text { 2019) }\end{array}$ \\
\hline & & 2922.21 & $2915-2935$ & $\mathrm{C}-\mathrm{H}$ methylene & (Coates, 2000) \\
\hline & & 2853.43 & $2845-2865$ & $\mathrm{C}-\mathrm{H}$ stretch $\left(>\mathrm{CH}_{2}\right)$ & $\begin{array}{l}\text { (Dovbeshko et al., } \\
\text { 2000) }\end{array}$ \\
\hline & & 1746.49 & $1725-1750$ & $\mathrm{C}=\mathrm{O}$ ester & $\begin{array}{l}\text { (Coates, 2000; } \\
\text { Saifuddin et al., } \\
\text { 2014) }\end{array}$ \\
\hline & & 1458.54 & $1430-1470$ & Methyl C-H bend & (Coates, 2000) \\
\hline & & 1377.21 & $1370-1420$ & $\begin{array}{l}\text { Glycerol group }\left(\mathrm{O}-\mathrm{CH}_{2}\right) \\
\text { Organic sulfates }\end{array}$ & $\begin{array}{l}\text { (Dube et al., 2004, } \\
\text { Coates, 2000) }\end{array}$ \\
\hline & & 1169.29 & $1130-1190$ & $\mathrm{CN}$ stretch & (Coates, 2000) \\
\hline & & 805.83 & $800-860$ & $\mathrm{C}-\mathrm{H}$ bond & (Coates, 2000) \\
\hline & & 722.28 & $700-800$ & C-Cl stretch & (Coates, 2000) \\
\hline
\end{tabular}


Table 1 (continue). FTIR peaks identified in various fuels

\begin{tabular}{|c|c|c|c|c|c|}
\hline \multirow[t]{2}{*}{ No. } & \multirow[t]{2}{*}{ Fuel } & \multicolumn{2}{|c|}{ Wavenumber $\left(\mathrm{cm}^{-1}\right)$} & \multirow{2}{*}{$\begin{array}{c}\text { Functional Group/ } \\
\text { Assignment }\end{array}$} & \multirow[t]{2}{*}{ Literature } \\
\hline & & Experiment & Literature & & \\
\hline \multirow[t]{8}{*}{3} & BD5 & 2954.46 & $2950-2970$ & $\mathrm{C}-\mathrm{H}$ methyl stretch $\left(\mathrm{CH}_{3}\right)$ & $\begin{array}{l}\text { (Coates, 2000; } \\
\text { Nandiyanto et al., } \\
\text { 2019) }\end{array}$ \\
\hline & & 2922.23 & $2915-2935$ & $\mathrm{C}-\mathrm{H}$ methylene & (Coates, 2000) \\
\hline & & 2853.23 & $2845-2865$ & $\mathrm{C}-\mathrm{H}$ stretch $\left(>\mathrm{CH}_{2}\right)$ & $\begin{array}{l}\text { (Dovbeshko et al., } \\
2000)\end{array}$ \\
\hline & & 1746.55 & $1725-1750$ & $\mathrm{C}=\mathrm{O}$ ester & $\begin{array}{l}\text { (Coates, 2000; } \\
\text { Saifuddin et al., } \\
\text { 2014) }\end{array}$ \\
\hline & & 1458.40 & $1430-1470$ & Methyl C-H bend & (Coates, 2000) \\
\hline & & 1377.12 & $1370-1420$ & Organic sulfates & $\begin{array}{l}\text { (Dube et al., 2004; } \\
\text { Coates, 2000) }\end{array}$ \\
\hline & & 1169.01 & $1130-1190$ & $\mathrm{CN}$ stretch & (Coates, 2000) \\
\hline & & 805.95 & $800-860$ & $\mathrm{C}-\mathrm{H}$ bond & (Coates, 2000) \\
\hline \multirow[t]{11}{*}{4} & BDW18.7 & 3395.76 & $3200-3570$ & $\begin{array}{l}\mathrm{O}-\mathrm{H} \text { stretch alcohol } \mathrm{O}-\mathrm{H} \\
\text { Stretch hydrogen } \\
\text { bonding }\end{array}$ & $\begin{array}{l}\text { (Coates, 2000; Rabelo } \\
\text { et al., 2015; Soares et } \\
\text { al., 2008) }\end{array}$ \\
\hline & & 2954.42 & $2950-2970$ & $\begin{array}{l}\mathrm{C}-\mathrm{H} \text { methyl stretch } \\
\left(-\mathrm{CH}_{3}\right)\end{array}$ & (Wu et al., 2001) \\
\hline & & 2922.29 & $2915-2935$ & $\mathrm{C}-\mathrm{H}$ methylene & (Coates, 2000) \\
\hline & & 2853.56 & $2845-2865$ & $\mathrm{C}-\mathrm{H}$ stretch $\left(>\mathrm{CH}_{2}\right)$ & $\begin{array}{l}\text { (Dovbeshko et al., } \\
\text { 2000) }\end{array}$ \\
\hline & & 1746.30 & $1725-1750$ & $\mathrm{C}=\mathrm{O}$ Ester & $\begin{array}{l}\text { (Coates, 2000; } \\
\text { Saifuddin et al., 2014) }\end{array}$ \\
\hline & & 1707.18 & $1700-1725$ & Carbonyl acid & (Coates, 2000) \\
\hline & & 1641.18 & $1550-1650$ & $\mathrm{~N}-\mathrm{H}$ bend (Amine) & (Coates, 2000) \\
\hline & & 1545.19 & $1540-1560$ & $\begin{array}{l}\text { Aliphatic nitro } \\
\text { compounds }\end{array}$ & (Coates, 2000) \\
\hline & & 1458.22 & $1430-1470$ & Methyl C-H bend & (Coates, 2000) \\
\hline & & 1377.21 & $1370-1420$ & Organic sulfates & $\begin{array}{l}\text { (Dube et al. 2004, } \\
\text { Coates, 2000) }\end{array}$ \\
\hline & & 1168.95 & $1130-1190$ & $\mathrm{CN}$ stretch & (Coates, 2000) \\
\hline
\end{tabular}


105 | Indonesian Journal of Science \& Technology, Volume 5 Issue 1, January 2020 Hal 95-108

Table 1 (continue). FTIR peaks identified in various fuels

\begin{tabular}{|c|c|c|c|c|c|}
\hline \multirow[t]{2}{*}{ No. } & \multirow[t]{2}{*}{ Fuel } & \multicolumn{2}{|c|}{ Wavenumber $\left(\mathrm{cm}^{-1}\right)$} & \multirow{2}{*}{$\begin{array}{c}\text { Functional Group/ } \\
\text { Assignment }\end{array}$} & \multirow[t]{2}{*}{ Literature } \\
\hline & & Experiment & Literature & & \\
\hline & & 805.95 & $800-860$ & $\mathrm{C}-\mathrm{H}$ bond & (Coates, 2000) \\
\hline & & 721.90 & $700-800$ & $\mathrm{C}-\mathrm{Cl}$ stretch & (Coates, 2000) \\
\hline \multirow[t]{11}{*}{5} & BDW24.7 & 3395.54 & $3200-3570$ & $\mathrm{O}-\mathrm{H}$ stretch alcohol & (Coates, 2000; \\
\hline & & & & $\begin{array}{l}\mathrm{O}-\mathrm{H} \text { Stretch hydrogen } \\
\text { bonding }\end{array}$ & $\begin{array}{l}\text { Rabelo et al., 2012, } \\
\text { Soares et al., 2008) }\end{array}$ \\
\hline & & 2954.21 & $2950-2970$ & $\begin{array}{l}\mathrm{C}-\mathrm{H} \text { methyl stretch } \\
\left(-\mathrm{CH}_{3}\right)\end{array}$ & (Wu et al., 2001) \\
\hline & & 2922.15 & $2915-2935$ & $\mathrm{C}-\mathrm{H}$ methylene & (Coates, 2000) \\
\hline & & 2853.14 & $2845-2865$ & $\mathrm{C}-\mathrm{H}$ stretch $\left(>\mathrm{CH}_{2}\right)$ & $\begin{array}{l}\text { (Dovbeshko et al., } \\
2000 \text { ) }\end{array}$ \\
\hline & & 1745.86 & $1725-1750$ & $\mathrm{C}=\mathrm{O}$ Ester & $\begin{array}{l}\text { (Coates, 2000; } \\
\text { Saifuddin et al., } \\
2014)\end{array}$ \\
\hline & & 1707.56 & $1700-1725$ & Carbonyl acid & (Coates, 2000) \\
\hline & & 1545.52 & $1540-1560$ & $\begin{array}{l}\text { Aliphatic nitro } \\
\text { compounds }\end{array}$ & (Coates, 2000) \\
\hline & & 1458.06 & $1370-1420$ & Organic sulfates & (Coates,2000) \\
\hline & & 1377.11 & $1370-1420$ & Organic sulfates & $\begin{array}{l}\text { (Dube et al., 2004; } \\
\text { Coates, 2000) }\end{array}$ \\
\hline & & 721.57 & $700-800$ & $\mathrm{C}-\mathrm{Cl}$ stretch & (Coates, 2000) \\
\hline
\end{tabular}

Figures $8,9,10,11$, and 12 show the FTIR result from BD100, BW18.7, BW24.7, $\mathrm{BD} 5$, and $\mathrm{BD} 10$, respectively. In the region from 1800 to $1700 \mathrm{~cm}^{-1}$, it can be seen that the peaks occur, which can signal to the ester $\mathrm{C}=\mathrm{O}$ stretch, commonly known as fatty acid methyl ester (FAME). Another important feature is that BD100, BW18.7, and BW24.7 have a different spectrum in the region of $3550-3200 \mathrm{~cm}^{-1}$. This spectrum can be defined as $\mathrm{O}-\mathrm{H}$ stretch of the hydrogen bond (Soares et al., 2008).

The composition of the fuel can affect the infrared spectroscopy. BD5, BD10,
BDW18.7, and BDW24.7 were blended with diesel oil; therefore, the organic sulfate stretch can be found in the FTIR figures. BDW18.7 and BDW24.7 included water additives; therefore, the $\mathrm{O}-\mathrm{H}$ hydrogen bond could be found in the infrared spectroscopy figures.

\section{CONCLUSION}

The addition of additives in waterbiodiesel oil increases the viscosity, density, and flash point. However, it lowers the cetane index and the caloric value. The distillation of BDW18.7 is nearly the same as that of BD10. This can signify that BDW18.7 
has better spray characteristics than BDW24.7. The infrared spectroscopy figures of BDW24.7 and BDW18.7 indicated strong $\mathrm{O}-\mathrm{H}$ hydrogen bonds from water additives. The organic sulfate stretch can be found in BD5, BD10, BW24.7, and BW18.7 because the oils were blended with diesel oil. The different compositions of the fuels can affect the infrared spectroscopy figures.

\section{ACKNOWLEDGEMENTS}

The first author would like to thank for Directorate General of Higher Education of the Ministry of Education and culture of Indonesia, Doshisha University and Dr. Muhammad Hafnan of the Mechanical Engineering Department, Trisakti University that have supported this research.

\section{AUTHORS' NOTE}

The authors declare that there is no conflict of interest regarding the publication of this article. The authors confirmed that the data and the paper are free of plagiarism.

\section{REFERENCES}

Abdurahman, N. H., Rosli, Y. M., Azhari, N. H., \& Adam, A. A. (2016). The potential of a water -indiesel emulsion for increased engine performance and as an enviromentally friendly fuel. Matec Web Conferences, 70, 01003.

Anggono, W., Noor, M. M., Suprianto, F. D., Lesmana, L. A., Gotama, G. J., \& Setiyawan, A. (2018). Effect cerbera manghas biodiesel in diesel engine performance. International Journal of Automotive and Mechanical Engineering, 15(3), 5667-5682.

Armas, O., Ballesterosa, R., Martosb, F. J., \& Agudeloc, J. R. (2005). Characterization of light duty diesel engine pollutant emissions using water-emulsified fuel. Fuel, 84(7-8), 1011-1018.

Awang, R., \& May, C. W. (2008). Water-in-oil emulsion of palm biodiesel. Journal of Oil Palm Research, 20, 571-576.

Ballester, J. M., Fueyo, N., \& Dopazo, C. (1996). Combustion characteristics of heavy oil-water emulsions . Fuel, 75(6), 695-705.

Barone, J. R. (2007). 233 ${ }^{\text {rd }}$ ACS National meeting. Paper AGRO-153. Chicago. 25-29.

Bhikuning, A. (2008). Nano Technology for new alternative energy. National Seminar Industrial Engineering. Trisakti University. Jakarta.

Bhikuning, A., Matsumura, E., Senda, J. (2018). Fuel analysis of jatropha methyl ester and $\mathrm{n}$-tridecane as an alternative fuel for the future. Matec Web of Conferences 153, 01002. https://doi.org/10.1051/matecconf/201815301002

Borhanipur, M., Karin, P., Tangroon, M., Chullacoop, N., \& Hanamura, K. (2014). Comparison study on fuel properties of biodiesel from jatropha, palm and petroleum based diesel fuel. $S A E$ International. TSAE-14IC-2017.

Chhetri, A. B., Watts, K. C., \& Islam, M. R. (2008). Waste cooking oil as an alternative feedstock for biodiesel production. Energies, 1(1), 3-18.

Coates, J. (2000). Interpretation of infrared spectra, a practical approach. Encyclopedia of analytical chemistry, 12, 10815-10837. 
107 | Indonesian Journal of Science \& Technology, Volume 5 Issue 1, January 2020 Hal 95-108

Cook, D. H., \& Law, C. K. (1978). A preliminary study on the utilization of water-in-oil emulsion in diesel engines, Combustion Science Technology, 18(5), 217-221.

Cunha, C. L., Luna, A. S., Oliveira, R. C. G., Xavier, G. M., Paredes, M. L. L., \& Torres, A. R. (2017). Predicting the properties of biodiesel and its blends using mid-FTIR spectrometry and firstorder multivariate calibration. Fuel, 204, 185-194.

Dovbeshko, G. I., Gridina, N. Y., Kruglova, E. B., \& Pashchuk, O. P. (2000). FTIR spectroscopy studies of nucleic acid damage. Talanta, 53(1), 233-246.

Dube, M. A., Zheng, S., Mclean, D. D., \& Kates, M. J. A. (2004). Comparison of attenuated total reflectance-FTIR spectroscopy and GPC for monitoring biodiesel production. Journal of the American Oil Chemist Society, 81(6), 599-603.

Farobie, O., \& Hasanah, N. (2016). Artificial Neural network approach to predict biodiesel production in supercritical tert-butyl methyl ester. Indonesian Journal of Science \& Technology, 1(1), 2336.

Hafnan, M. (2008). Patent registered no. P00200800511. $1^{\text {st }}$ August.

Juan, J. C., Kartika, D. A., Wu, T. A., \& Hin, T. Y. Y. (2011). Biodiesel production from jatropha oil by catalytic and non-catalytic approaches: an overview. Bioresource Technology, 102(2), 452-460.

Karim, Z. A. A., Khan, M. Y., Aziz, A. R. A., \& Tan, I. M. (2014). Characterization of water in diesel emulsion. Matec Web Conferences, 13, 02006.

Kinoshita, E., Hamasaki, K., Jaqin, C., \& Takasaki, K. (2004). Combustion characteristics for diesel engines with emulsified biodiesel without adding emulsifier. SAE Technical paper, 2004-011860.

Knothe, G., Matheaus, A. C., \& Ryan III, T. W (2003). Cetane numbers of branched and straught-chain fatty esters determined in an ignition quality tester. Fuel, 82(8), 971-97.

Lawson, A., Vergeer, E. C., Mitchell, E. W., \& Dainty, E. D. (1986). Heavy-duty diesel emission control: a review of technology. Montreal, Quebec, Canada: CIM, 36, 238.

Lif, A., \& Holmberg, K. (2006). Water-in-diesel emulsions and related systems. Advances in Colloid and Interface Science, 123, 231-239.

Nandiyanto, A. B. D., Putra, Z. A., Andika, R., Bilad, M. R., Kurniawan, T., Zulhijah, R., \& Hamidah, I. (2017). Porous activated carbon particles from rice straw waste and their adsorption properties. Journal of Engineering Science and Technology, 12, 1-11.

Nandiyanto, A. B. D., Oktiani, R., \& Ragadhita, R. (2019). How to read and interpret FTIR spectroscope of organic material. Indonesian Journal of Science \& Technology, 4(1), 97-118.

Narkpakdee, J., Permsuwan, A., Deethayat, T., \& Kiatsiriroat, T. (2012). Performance and emission of small diesel engine using diesel-crude palm oil-water emulsion as fuel. Energy Science \& Technology, 3(2), 38-45.

Nayaggy, M., \& Putra, Z. A. (2019). Process simulation on fast pyrolysis of palm kernel shell for production of fuel. Indonesian Journal of Science \& Technology, 4(1), 64-73.

Rabelo, S. N., Ferraz, V. P., Oliveira, L. S., \& Franca, A. S. (2015). FTIR analysis for quantification of fatty acid methyl esters in biodiesel produced by microwave-assisted transesterification. International Journal of Environmental Science and Development, 6(12), 964-969. 
Saifuddin, N., \& Refai, H. (2014). Spectroscopy analysis of structural transesterification in biodiesel degredation. Research Journal of Applied Sciences, Engineering and Technology, 8(9), 1149-1159.

Senthur, N. S., \& Ravikumar, T. S. (2016). An experimental investigation on performance, combustion and emission parameters biodiesel-water emulsion on a DI diesel engine. International Journal of Engineering Sciences \& Research Technology, 5(8), 54-62.

Soares, I. P., Rezende, T. F., Silvia, R. C., Castro, V. R., \& Forte, I. C. P. (2008). Multivariate calibration by variable selection for blends of raw soybean oil/biodiesel from different sources using fourier transform infrared spectrocospy (FTIR) spectra data. Energy \& Fuels, 22(3), 2079-2083.

Subramanian, K. A. (2011). A comparison of water-diesel emulsion and timed injection of water into the intake manifold of a diesel engine for simultaneous control of $\mathrm{NO}$ and smoke emissions. Energy Convers Manage, 52(2), 849-57.

Wu, J. G., Xu, Y. Z., Sun, C. W., Soloway, R. D., Xu, D. F., Wu, Q. G., \& Xu, G. X. (2001). Distinguishing malignant from normal oral tissues using FTIR fiber-optic techniques. Biopolymers: Original Research on Biomolecules, 62(4), 185-192.

Xuea, J., Grift, T. E., \& Hansen. A. C. (2011). Effect of biodiesel on engine performances and emissions: Renewable and Sustainable Energy Reviews, 15(2), 1098-111.

Yoshimoto, Y., Onodera, M., \& Tamaki, H. (1999). Reduction of NOx, smoke and BSFC in a dieselengine fuelled by biodiesel emulsion with used frying oil. SAE Transaction,1913-1920. 